\title{
Relationship of Body Mass Index (BMI) and Sex in Adolescent Training Resistance
}

\author{
Tyas Sari Ratna Ningrum ${ }^{1}$, Ummy Aisyah Nurhayati ${ }^{1}$ \\ Fakultas Ilmu Kesehatan Universitas Aisyiyah Yogyakarta ${ }^{1}$ \\ E-mail : tyassariratnaningrum@unisayogya.ac.id \\ 082227393491 \\ *E-mail: korespondensi@domain.com \\ https://doi.org/10.30787/gaster.v19i1.658
}

\section{ARTICLE INFO}

Keywords: Body Mass Index; Sex; VO2Max

\section{ABSTRACT}

Adolescents 18-21 years of age today have problems related to movement that result in changes to resistance training. Exercise resistance is expressed in VO2max. Body mass index and gender are factors that influence VO2max. The purpose of this study is to analyze the relationship between body mass index and sex on VO2Max and to analyze how closely the relationship is. The type of this study is an observational study with a purposive sampling technique with a point time approach design with a total of 183 samples with criteria for healthy samples aged 1821 years. The independent variable in this study was exercise endurance (VO2max), and the dependent variable was body mass index and gender. The data is processed using software for data analysis. From the data normality test using Kolmogorov Smirnov for Body Mass Index data with a value of 0.001, sex data with a value of 0.000, VO2Max data with a value of 0.000 which indicates abnormal data. Test Data analysis using the Spearman rank test resulted in the value of gender and VO2max 0.001 with $r$ value of 0.203 and body mass index value and VO2max -0.015 with $r$ value of 0.766.There is a correlation between body mass index and sex on VO2Max.

\section{INTRODUCTION}

People do structured and planned activities that involve repetitive body movements can increase the optimal level of physical fitness. A high level of physical fitness will help improve cardiovascular health and can restore various risk factors for other diseases. When people do activities, 
someone who has a high level of physical fitness will not feel tired easily and they able to work longer hours. In essence, physical fitness is the body.s ability to carry out daily activities properly and efficiently without causing significant fatigue and the body still stores sufficient energy for sudden needs and to enjoy other free time (Emaus et al., 2011). If someone has a good level of fitness, it will produce good work and higher readiness to do the activities (Nawawinetu, ED. dan Lutfiya, 2020).

Young people (adolescents) aged 1821 years today have problems related to movement which result in an increase in body mass index due to fat accumulation and decreased physical fitness. Physical fitness is a condition that reflects a person.s ability to perform tasks productively without experiencing significant fatigue. Decreased physical activity experienced by adolescents now will reduce physical fitness (Ningrum Ratna, Nurhayati, 2021).

The decrease and increase the physical fitness level can be maintained if they are diligent in exercising (Maharja, 2015). The physical fitness level will reach a maximum at the age of 30 years and has a peak at the adolescent level at the age of 18-21 years. The increasing age will make the physical activity decreases (Chandler, 2019). When a person enters the world of work, his activities start to take up his time, so that the frequency of his activities decreases (Sharkey, B.J., 2011). Each age level has a different level of physical fitness and can be improved at almost any age. Furthermore, there will be a decrease in the functional capacity of all organs of the body by approximately 0.81$1 \%$. However, by exercising diligently, the speed of this decline can be slowed down by half/half (Noor, Kinanti, Rias Gesang, Andiana, olivia, 2015).

There are differences in physical fitness for men and women after puberty. Men have a higher fitness level than women (Shaikh, Patel and Singh, 2011). This difference is due to differences in muscular power related to muscle development and muscle strength (Manansang, GR. Rumampuk, JF. dan Moningka, 2018). Physiologically, hormonal factors greatly influence the dominance of muscle fiber growth so that it greatly affects muscle strength so that it also affects endurance in training (VO2max) (Shargal, E. Cohen, R.K. Zigel, L. Epstein, S. Burstein, R.P. Tenenbaum, 2014).

The weight and height factors will form the body mass index unit which will affect the VO2max (Milner, 2013). The ideal body 
mass index will maximize VO2max. The use of more energy will make the need for oxygen much greater which will spur the heart to work harder. This can be experienced in someone who has an excess body mass index (Limanan and Prijanti, 2013).

\section{METHODS AND MATERIALS}

The research was carried out in late adolescent students aged 18-21 years at Aisyiyah University Yogyakarta which was conducted during September-November. The type of research to be used is observational with a cross-sectional descriptive approach, which is a study that studies the dynamics of the correlation between risk factors and effects. The research design uses the Point Time Approach.

The criteria sample of this study are of all students aged 18-21 years with a healthy condition, no history of cardiovascular and respiratory disorders, not experiencing neuromuscular disorders that could interfere with the study. In conducting the research, there were 183 people.

In this research used tools in the form of digital scales, midline height, box with a height of $45 \mathrm{~cm}$ are needed. The implementation of this research begins with submitting ethical clearances, then continues with measurements in measurements in this study, the sample will be asked to take measurements of body weight and height then the results are entered into the formula to obtain body mass index data, then proceed with questions and answers on sex. Then proceed with the measurement of VO2max using the Harvard step test method. The test will be stopped when any symptoms appear: shaking, cold sweat, loss of balance, dizziness, and pale.

After the data is collected, the data is entered into data calculating software and then coded in each data, namely the body mass index, gender and VO2max. Then the univariate and bivariate data analysis tests were carried out using data processing software. The normality test used the Kolmogorov Smirnov test and then correlation test using the Spearman rank test.

\section{RESULTS AND DISCUSSION}

In the following decomposition contains a description of the results of data analysis. The results of the normality test using the Kolmogorov Smirnov test show the following data: 
Table 1. Results of the Kolmogrov Smirnov test for normality test

\begin{tabular}{lcc}
\hline & \multicolumn{2}{c}{ Kolmogorov-Smirnov } \\
\cline { 2 - 3 } & $\mathrm{N}$ & Sig. \\
\hline BMI & 183 & 0,001 \\
Sex & 183 & 0,000 \\
VO2max & 183 & 0,001 \\
\hline
\end{tabular}

From these data, it shows that the $p$ value (sig) is below the confidence value of 0.05 , so the data is not normal. Therefore, it is continued with the Spearman rank test for ordinal and abnormal data types. From the results of the spearman rank test which shows the results:

Table 2. Results of the Relationship between BMI, Sex and VO2max

\begin{tabular}{llll}
\hline Uji & Variabel & Ket & Hasil \\
\hline Sperman Rank & BMI and VO2max & Correlation Coefficient & 0.766 \\
& & Sig. (2-tailed) & -0.015 \\
& N & 183 \\
& Sex and VO2max & Correlation Coefficient & 0.203 \\
& Sig. (2-tailed) & 0.001 \\
& N & 183 \\
\hline
\end{tabular}

Based on the data above, it shows that the relationship between body mass index and VO2 max shows a sig value of -0.015 which means that there is a negative relationship between BMI and VO2max. This negative relationship can be interpreted that the smaller the BMI, the higher the VO2max, with an $r$ value of 0.766 , which means that there is a very strong relationship between the two variables. Meanwhile, the relationship between gender and VO2max shows a sig value of 0.001 , which means that there is a relationship between gender and VO2 max with an $r$ value of 0.203 , which means that there is a weak relationship between the two variables.

\section{DISCUSSION}

1. Relationship between Gender and Youth.s VO2Max with low closeness

The results of data processing for the relationship between gender and 
adolescent $\mathrm{VO} 2 \max$ are $\mathrm{p}$ value 0.001 with $\mathrm{r}$ value 0.203 , which means that there is a relationship between gender and VO2max with low closeness.

This difference in $\mathrm{VO} 2 \max$ values between men and women is associated with higher hemoglobin levels as well as lower body fat in men compared to women. Women have less muscle mass and more fat mass than men. This makes the aerobic fitness of women will be lower than that of men (Buana, 2012). Then a higher hemoglobin level in men than women causes a difference in blood carrying capacity which causes men to get much more oxygen during the process of physical activity so that their aerobic capacity is better (Ningrum, 2018).

The maturation of each individual is different, but the average VO2Max value is the same for boys and girls under the age of 12. After 12 years of age, boys. VO2Max increased until 18 years of age, whereas women.s VO2Max values changed little after age 1420. At the age of puberty, puberty status and episodes of growth spurt are different for each child. Growth spurt will significantly increase the VO2Max value. This is related to the rapid increase in muscle mass, especially in skeletal muscles (Sharkey, B.J., 2011).
Research on VO2max has been carried out in several countries and the results show that the VO2max value in the studied population is still low or below the standard (a good standard of $\mathrm{VO} 2 \mathrm{max}$ is $\geq 39 \mathrm{ml} / \mathrm{kg} /$ minute for women and $\geq 44 \mathrm{ml} / \mathrm{kg} /$ minute for men (Katch, 2011).

Research on 18 year old Spanish boys and girls showed that their mean VO2max values were $42.5 \mathrm{ml} / \mathrm{kg} /$ minute and $36.8 \mathrm{ml} / \mathrm{kg} /$ minute, respectively 23 . In addition, research on Greek adolescent boys showed their mean VO2max was $34.7 \mathrm{ml} / \mathrm{kg} / \mathrm{min} 13$. Then, a similar study was also conducted on male and female adolescents in China which showed that their mean VO2max values were 39.4 $\mathrm{ml} / \mathrm{kg} /$ minute and $35.1 \mathrm{ml} / \mathrm{kg} /$ minute, respectively (Sun et al., 2011).

The VO2max value is known to be associated with several factors, one of which is gender ${ }^{5}$. Research conducted on Italian and Portuguese adolescents using the $20 \mathrm{~m}$ shuttle run test method found a significant relationship between $\mathrm{VO} 2 \mathrm{max}$ values and gender. In this study, it was found that the VO2max value in boys was better than that in girls (Ningrum et al., 2021). 
The maximal aerobic ability (VO2 $\max )$ in women is lower than that of men, which is around 15-25\% (Buana, 2012). The difference in VO2 max between the sexes is not seen at a young age, most clearly during adulthood or middle age (Manansang, GR. Rumampuk, JF. dan Moningka, 2018). This is related to the fact as mentioned earlier that the difference in body size and body composition between men and women is very small before puberty but the difference is very large in adulthood (Connor, Stephanie, 2020).

\section{The relationship between BMI and}

\section{VO2Max in adolescents}

The results of data processing for the relationship between BMI and VO2max adolescents are with a $\mathrm{p}$ value of 0.049 with an $r$ value of 0.814 , which means that there is a relationship between BMI and VO2max with high closeness.

Body Mass Index (BMI) relates to a person.s body fat and is related to both underweight and overweight, calculated as weight in kilograms divided by height in meters squared $(\mathrm{kg} / \mathrm{m} 2)$. A person.s VO2Max is influenced by several factors including heredity, age, gender, body composition and exercise or exercise. BMI is a simple way to monitor nutritional status, especially in relation to underweight and overweight (Ristianingrum, I. Rahmawati I. dan Rujito, 2019).

In a more in-depth study, it can also explain excess weight loss in relation to VO2Max. Individuals who have excess normal body weight will certainly have more fat folds. Meanwhile, a person.s VO2Max is largely determined by factors of age, gender, genetics, body composition, and physical activity. Among these 5 factors, body composition and physical activity play a significant role. VO2Max means the volume of oxygen that the body can use when working as hard as possible (Limanan and Prijanti, 2013).

The high body fat will be a barrier and give additional burden to the cardiorespiratory function during physical exercise (Shaikh Wasim A., Minal C. Patel, 2011). This reduced function will result in the low uptake of oxygen which is used for intracellular metabolism, especially musculoskeletal cells (Emaus et al., 2011). Due to disproportionate deposition of fat, the musculoskeletal system fails to obtain sufficient amounts of oxygen during exercise (Alamsyah 
Nurul, DA. Hestiningsih, R. dan Saraswati, 2017).

It can be seen from previous research that the VO2Max value at normal body weight is better than the underweight or overweight body weight. This can occur because VO2Max is determined by nutritional status, especially by energy reserves and mitochondrial function. In people who are underweight there is a lack of energy for the gluconeogenesis process. This will reduce physical activity so that VO2Max ability will decrease (Andhika, 2013). In addition to decreased physical abilities, people who are underweight also experience a $30 \%$ reduction in basal metabolism and cell reaction rate and a decrease in the oxidative phosphorylation process (Milner, 2008). A decrease in the speed of cell reactions and the oxidative phosphorylation process will result in a decrease in the ability to adapt to hypoxic states that can occur when activity is long and at maximum intensity, so that the VO2Max value is lower (Connor, 2020).

The increase in BMI is ideal so that VO2Max can be better because it is supported by a more proportional body ${ }^{1}$. Individuals who have an overweight BMI will certainly have more fat composition
(Ortega, Ruiz and Castillo, 2008). The high body fat will be a barrier and give additional burden to the cardiorespiratory function during physical activity. This reduced function will result in the low uptake of oxygen which is used for intracellular metabolism, especially musculoskeletal cells (Andhika, 2013).

Due to disproportionate deposition of fat, the musculoskeletal system fails to obtain sufficient amounts of oxygen during physical activity. In the body, the increasing number of adipose tissue will be accompanied by increased levels of leptin in the bloodstream (Ellis, 2006). With the higher leptin in the blood, the binding of leptin to the receptors also causes more contraction of the cardiomyocytes to decrease (Limanan and Prijanti, 2013). The reduced contraction of cardiomyocytes will cause the supply of $\mathrm{O} 2$ to the body muscles to also decrease (Wibowo, C. dan Dese, 2019). This condition results in a lack of $\mathrm{O} 2$ in the muscles resulting in a decrease in muscle work. This decrease in muscle work resulted in fatigue in respondents (Maharja, 2015).

Excess body fat increases body mass so that according to Newton.s 
Second Law it decreases acceleration (motion). Increasing body weight will lead to greater energy requirements for the aerobic system to carry out and carry out body movements (Limanan and Prijanti, 2013). Therefore, being overweight generally causes fatigue that is much earlier when given a load during activities (Noor, Kinanti, Rias Gesang, Andiana, olivia, 2015).

Increasing the amount of body fat will increase the number of mitochondria to meet energy needs. The increase in the number of mitochondraia will make the muscle size hypertrophic (Heni Puji Wahyuningsih dan Yuni Kusmiyati, 2017). The increase in muscle size will create inflammation in the blood vessels, causing endothelial dysfunction which causes narrowing of the blood vessels. When the blood vessels constrict, the amount of oxygen that is delivered to the heart decreases. As a result, the heart rate will increase to meet oxygen demand during activities (Nawawinetu, ED. dan Lutfiya, 2020).

\section{CONCLUSIONS AND SUGGESTIONS}

In accordance with the results of data analysis, there is a relationship between body mass index (BMI) and sex to VO2max in adolescents.

I hope the further research can use more detailed and variables, so that it can obtain new scientific variation.

\section{REFERENCES}

Alamsyah Nurul, DA. Hestiningsih, R. dan Saraswati, L. (2017) 'Faktorfaktor yang berhubungan dengan kebugaran jasmani pada remaja siswa kelas xi smk negeri 11 semarang', JURNAL KESEHATAN MASYARAKAT (e-Journal), 5, pp. 77-86.

Andhika, B. (2013) 'Analisis Status Gizi dan VO2Max Pada Pemain Sepak Bola', Jurnal Analisis Status Gizi Dan Vo2 Max Pada Pemain Sepakbola. Volume 01 Nomor 01 Tahun 201, 0 - 216, pp. 201-216.

Buana, G. C. (2012) Hubungan Antara Kebugaran Hubungan Antara Kebugaran Kardiorespirasi Dengan TekananDarah Pada Wanita. University of Muhammadiyah Surakarta.

Connor, S. (2020) connor What Is VO2 Max, and How Does It Affect Your Fitness_ _openfit. 
Emaus, A. et al. (2011) 'Blood pressure, cardiorespiratory fitness and body mass : Results from the Tromsø Activity Study', Norsk Epidemiologi, 20(2), pp. 189-197.

Harold Ellis (2006) Clinical anatomy. 11th edn, Clinical Anatomy Applied Anatomy For Students and Junior Doctors. 11th edn. Australia: Blackwell Publishing Ltd. doi: 10.1007/978-3-319-157351 1.

Heni Puji Wahyuningsih dan Yuni Kusmiyati (2017) Anatomi Fisiologi. Indonesia: Kementrian Kesehatan Indonesia.

Katch (2011) Essentials of exercise physiology (4th ed.). 4th edn. USA: Lipincott Williams and Wilkins.

Limanan, D. and Prijanti, A. R. (2013) 'Hantaran Sinyal Leptin dan Obesitas : Hubungannya dengan Penyakit Kardiovaskuler', Journal Biomedic, 1(2).

Maharja, R. (2015) ‘Analisis tingkat kelelahan kerja berdasarkan beban kerja fisik perawat di instalasi rawat inap rsu haji surabaya', The Indonesian Journal of Occupational Safety and Health Vol 4 No 1 Jan-Jun 2015 : 93-102, pp. 93102.
Manansang, GR. Rumampuk, JF. dan Moningka, M. (2018) 'Perbandingan Tekanan Darah Sebelum dan Sesudah Olahraga Angkat Berat', Jurnal e-Biomedik (eBm), 6 .

Milner, C. E. (2008) F unc t $i$ on a l A $n$ a to $m y$ for $S p$ ort and Exer c is e. USA: Routledge.

Nawawinetu, ED. dan Lutfiya, I. (2020) 'FACTORS ASSOCIATED WITH THE ABILITY TO PERFORM PHYSICAL FITNESS TESTS WITH QCST, Journal of Vocational Health Studies, 03, pp. 97-102. doi: 10.20473/ jvhs.V3I3.2020.97.

Ningrum Ratna, T. S., Nurhayati, U. A. and Yogyakarta, U. A. (2021) 'Jurnal fisioterapi dan rehabilitasi', JURNAL FISIOTERAPI DAN REHABILITASI, 5(1), pp. 41-49.

Noor, Kinanti, Rias Gesang, Andiana, olivia, S. (2015) 'Korelasi obesitas sentral dan tingkat vo 2 maks pada pria di kota malang', Journal of sport, 1, pp. 113118.

Ortega, F. B., Ruiz, J. and Castillo, M. J. (2008) 'PEDIATRIC REVIEW Physical fitness in childhood and adolescence : a powerful marker 
of health', International Journal of Obesity, 32(March 2016), pp. 1-11. doi: 10.1038/sj.ijo.0803774.

Ratna Ningrum, T. S. (2018) 'Perbedaan pengaruh latihan active stretching,hold relax, dan contract relax terhadap peningkatan fleksibilitas togokpada adolescent ditinjau dari jenis kelamin', Journal of Health Studies, 2(2), pp. 9399. doi: 10.31101/jhes.474.

Ristianingrum, I. Rahmawati I. dan Rujito, L. (2019) 'Journal of Nutrition College', Journal of Nutrition College, 8, pp. 95-100.

Shaikh, W., Patel, M. C. and Singh, S. K. (2011) 'Association of physical activity and physical fitness with blood pressure profile in Gujarati Indian adolescents WITH BLOOD PRESSURE PROFILE IN GUJARATI INDIAN ADOLESCENTS', indian $J$ Phisiol Pharmacol, 55(4((January), pp. $322-328$

Shaikh Wasim A., Minal C. Patel, S. K. S. (2011) shaikh. Available at: https://www.researchgate.net/ publication/235383974_Association_ of_physical_activity_and_physical_ fitness_with_blood_pressure_profile_ in_Gujarati_Indian_adolescents.
Shargal, E. Cohen, R.K. Zigel, L. Epstein, S. Burstein, R.P. Tenenbaum, G. (2014) 'Age-related maximal heart rate: examination and refinement of prediction equations.', 55(10), pp. 1207-1218. Available at: https:// pubmed.ncbi.nlm.nih.gov/25389634/.

Sharkey, B.J. (2011) Kebugaran dan Kesehatan (Edisi Ke-2). Jakarta: Raja Grafindo Persada.

Stephanie Chandler (2019) Factors That Affect Heart Rate and Blood Pressure. Available at: https://www.livestrong. com/article/108483-factors-affectheart-rate-/.

Sun, M. et al. (2011) 'One-hour after-school exercise ameliorates central adiposity and lipids in overweight Chinese adolescents: A randomized controlled trial', Chinese Medical Journal, 124 (3) (February), pp. 323-329. doi: 10.3760/ cma.j.issn.0366-6999.2011.03.001.

Wibowo, C. dan Dese, D. . (2019) 'HUBUNGAN INDEKS MASA TUBUH DENGAN VO2MAX PADA ATLET BOLABASKET', Physical Education, Health and Recreation, 3(2), pp. 19-25. 